\title{
Pelatihan Penerapan Sport Science Untuk Pelatih Bulutangkis Di Kecamatan Masbagik
}

\author{
Lalu Sapta Wijaya Kusuma, \& Aminullah \\ Dosen IKIP Mataram
}

\begin{abstract}
Abstrak; Club atau persatuan bulutangkis di Kecamatan Masbagik yang diakui secara resmi keberadaannya oleh PBSI Lombok Timur ada dua yaitu; (1) PB. Lyansa dan PB. Nasional, walaupun ada beberapa pelatih yang aktif di Pringgasela, Selong dan sekitarnya. Sehingga dari hal tersebut bisa dikatakan bahwa pelatih yang mempunyai pengakuan oleh masyarakat hanya dari kedua club tersebut, akan tetapi hal tersebut mengindikasikan minimnya kesempatan dan kemampuan pelatih dalam mengembangkan kemampuan melatihnya dan meningkatkan prestasi atlet di level nasional bisa mengungguli klub-klub di pulau jawa sebagai penyumbang atelt Nasional. Selain dari kurangnya sarana dan prasarana, jumlah pelatih yang sangat kurang, dan kompetensi yang belum sangat memedai, sehingga penting kiranya hal tersebut menjadi perhatian dari PBSI Lotim ataupun pemerhati bulutangkis dalam meningkatkan kemampuan pelatih dalam menerapkan ilmu kepelatihannya pada anak yang di didiknya di klub masing-masing. Berkaitan dengan permasalahan tersebut diatas maka dalam hal ini kami menawarkan solusi peningkatkan kompetensi melalui pelatihan dengan; (1) memberikan pemahaman tentang cara membuat program latihan yang baik dan benar, (2) memberikan pemahaman tentang bagaimana menerapkan sport science, dan (3) memberikan pemahaman dan sekaligus dapat diaplikasikan mengenai tehnik pengukuran kondisi fisik dominan khusus atlet bulutangkis. Hasil dari program pengabdian ini tentunya peningkatan kualitas dan kuantitas pelatih dan atlet yang ada di Kecamatan Masbagik melalui kemitraan antara klub-klub (pelatih), sekolah, dan Institusi IKIP Mataram sehingga bersinergi dalam melahirkan dan menampung atlet berprestasi di masing klub dan sekolah kemitraan.
\end{abstract}

Kata Kunci: penerapan sport science, pelatih bulutangkis

\section{PENDAHULUAN}

Analisis Situasi

a. Mitra 1

SMA Muhammdiyah Masbagik merupakah sekolah yang berdiri sejak tahun 1981 dengan SK Pendirian Sekolah: A.1/22/1981 dengan SK Izin Operasional; 1750/120.1/82. Alamat: Jln. Pendidikan No. 25 Masbagik.

Fasilitas yang ada di sekolah ini antara lain 11 ruangan belajar yang dilengkapi dengan penyejuk udara, ruang guru dan kepala sekolah, perpustakaan, UKS, ruang komputer. kamar mandi, taman, Musholla, dan lapangan outdoor serbaguna.

Gambar 1.1 keadaan situasional sekolah SMA Muhammadiyah Masbagik

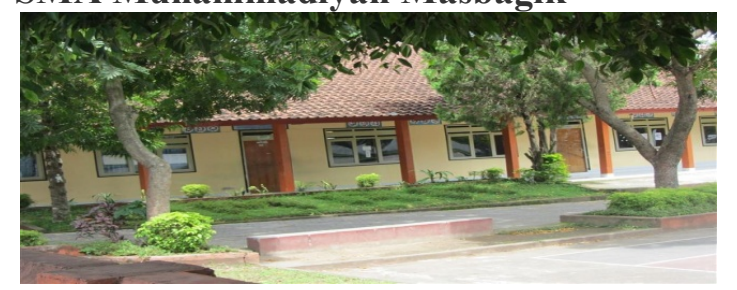

\section{b. Mitra 2}

Jumlah pelatih yang memiliki sekolah bulutangkis di Masbagik ada dua yaitu PB. Lyansa pimpinan Aziat, S.Pd dan PB. Nasional pimpinan Rusli. Kedua klub ini yang memfasilitasi para pecinta bulutangkis, baik dari usia dini sampai dengan tingkat dewasa. Keadaan tersebut tentunya cukup memperihatinkan untuk masyarakat yang ingin mengmbangkan kemampuannya di cabang olahraga bulutangkis. Kurangnya pelatih dan kompetensi pelatih menjadi kendala utama dalam mengambangkan olahraga bulutangkis di kecamatan masbagik, kedua; kurangnya sarana dan prasarana bulutangkis, dan yang ketiga adalah jumlah dari pelatih bulutangkis yang ada di masbagik yang mempunyai lisensi pelatih belum ada. Hal tersebut disebabkan beberapa faktor:

1) Kurangnya pelatihan yang diadakan oleh PBSI Provinsi maupun Kabupaten Kota

2) Kurangnya kesempatan bagi pelatih pemula dalam membina dan 
mengembangkan kompetensi yang dimiliki

3) Pelatih yang memiliki lisensi resmi dari BWF level 1 di NTB hanya 2 orang saja.

\section{Permasalahan Mitra}

Pelatih dari dari klub resmi maupun tidak resmi yang ada di kecamatan masbagik belum memiliki sertifikat atau lisensi kepelatihan. Hal ini disebabkan belum pernah dilakukan pelatihan pelatih yang berlisensi khususnya di Kabupaten Lombok Timur maupun ditingkat Provinsi di NTB. Pelatihan pelatih masih terfokus pengadaannya di luar daerah NTB sehingga pelatih dari NTB kesulitan mengikuti itu terkendala biaya, akomodasi, dan minimnya akses informasi mengenai pelatihan yang diadakan oleh PBSI pusat terkait peningkatan kompetensi pelatih.

Dari permasalahan yang dihadapi oleh mitra, maka melalui IbM ini diharapkan keterampilan dan kemampuan para pelatih meningkat, adanya wadah untuk mengatasi permasalahan kedua mitra, terbentuknya sekolah-sekolah bulutangkis di masingmasing Kecamatan yang ada di kabupaten Lombok Timur secara kuantitas. Solusi yang dilakukan adalah melakukan pelatih bagi pelatih dan memberikan jam terbang untuk menimba ilmu pelatihan diluar kota ataupun sejenisnya.

Kegiatan IbM "Pelatihan Penerapan Sport Science Untuk Pelatih Bulutangkis Kecamatan Masbagik", dengan target luaran berupa:

1. Peningkatan Kualitas dan kuantitas pelatih bulutangkis berkompeten

2. Peningkatan pemahaman dan keterampilan masyarakat akan pentingnya penerapan pengetahuan ilmu keolahragaan (sport science)

3. Bertambahnya klub-klub bulutangkis di kecamatan masbagik dan sekitarnya

4. Program yang diharapkan bisa berkelanjutan PBSI kabupaten Lombok Timur dan Provinsi

5. Publikasi ilmiah di jurnal

\section{METODE PELAKSANAAN}

Kursus kepelatihan bagi pelatih bulutangkis membutuhkan biaya yang banyak yaitu 5-6 juta untuk masing-masing peserta karena kursus tersebut mendatangkan instruktur level 3 BWF (lisensi tingkat dunia) dan lamanya kursus hampir seminggu, hal tersebut yang membuat kursus kepelatihan di NTB jarang diadakan. Dengan adanya dana internal ini diharpkan cukup mengakomodir kebutuhan mendasar para pelatih. Rencana kegiatan ini diikuti kurang lebih sekitar 10 orang pelatih yang ada di kecamatan masbagik dan sekitarnya, tanpa mengeluarkan biaya untuk membayar instruktur pelatihan yang ada di luar NTB.

Metode pelaksanaan pada IbM ini adalah berbentuk kursus kepelatihan singkat bagi para pelatih atau calon pelatih yang dilaksanakan selama 1 hari. Kegiatan tersebut terdiri dari 2 metode yaitu metode teori didalam ruangan, dan praktik di lapangan (GOR PB. Lyansa).

Adapun prosedur dalam pelaksanaan IbM ini adalah sebagai berikut:

1) Survei dan analisis lokasi dan mitra

2) Menganalisis kebutuhan mitra

3) Mengadakan komunikasi kerjasama dengan mitra 1 yaitu SMA Muhammadiyah Masbagik sebagai penyelenggara kursus kepelatihan yang bekerjasama dengan mitra 2 yaitu PB. Lyansa. Kedua mitra ini mengundang ketua masing-masing PB., pelatih, dan calon pelatih bulutangkis untuk mengikuti kursus pelatihan pelatih

4) Mengadakan pelatihan penerapan sport science selama 1 hari dengan teori dan praktik langsung di ruangan mengenai pengukuran komponen fisik dominan atlet bulutangkis, evaluasi, dan pembuatan materi latihan yang terprogram dengan baik.

\section{Partisipasi Mitra}

Mitra pertama kami yaitu SMA muhammdiyah masbagik merupakan tempat berkumpulnya siswa siswi atlet bulutangkis masbagik, sekaligus tempat pendaftaran peserta pelatihan dari pelatih, calon pelatih, dan atlet. Sedangkan mitra 2 kami adalah tempat diadakannya pelatihan dan sekaligus tempat putra putri terbaik masbagik berlatih di PB. Tersebut (PB. Lyansa). Peran keduanya nanti diharapkan bisa mengundang antusiasme pelatih dan calon pelatih untuk mengikuti kegiatan yang dimaksud. Selain itu 
juga pelatih dari PB. Lyansa Masbagik merupakan anggota dari PBSI Lombok Timur. Sehingga harapan kami sebagai tim pelaksana kegiatan berjalan dengan baik dan bisa meningkatkan kemampuan dan kompetensi bagi pelatih dan calon pelatih di Kecamatan Masbagik secara khusus.

\section{PELAKSANAAN KEGIATAN}

\section{Gambaran Umum Lokasi Kegiatan}

Lokasi kegiatan berpindah ke JM.

Resto Jalan raya kota Selong dikarenakan SMA Muhammadiyah mempunyai kegiatan guru dan siswa selama tuga hari, sehingga kegiatan tersebut kami alihkan ke JM. Resto. JM. Resto merupakan tempat rumah makan yang dimiliki oleh ketua umum KONI Lotim, sehingga pada proses pengadaan workshop tersebut berjalan sesuai dengan yang diharapkan.

\section{Gambaran Umum Peserta Kegiatan}

Kegiatan pengabdian dihadiri oleh pelatih bela diri tarung derajat yang berjumlah sekitar 15 orang. Dengan rincian; 9 pelatih dari terung derajat, 2 orang dari beladiri karate, dan 3 orang dari pelatih bulutangkis.

\section{Pelaksanaan Kegiatan}

Pelaksanaan kegiatan pengabdian kami gabung dengan pelatih beladiri dan pelatih bulutangkis, hal tersebut kami lakukan karena kekurangan dana diperoleh dari pengabdian. Penyewaan tempat dan pemateri dengan total anggaran sebesar Rp. 1.300.000 (satu juta tiga ratus ribu rupiah), yang tentunya dana yang kami keluarkan lebih besar dari dana yang didapatkan dari pihak LPPM. JM. Resto dipilih sebagai tempat pengabdian agar Ketua KONI Lotim berkenan memberikan subsidi untuk panitia agar pengeluaran dan konsumsi peserta pelatihan bisa di akomodir oleh panitia, dikarenakan konsumsi dan snack peserta ditanggung oleh panitia pelatihan.

Pelaksanaan kegiatan pengabdian dilaksanakan pada hari minggu dari jam 8.00 sampai dengan jam 5.30 sekaligus penutupan. Rincian kegiatan pengabdian tersebut dilakukan oleh 3 pemateri, yaitu; 1) Lalu Sapta Wijaya K., 2) Jamaludin, 3) Ir. Elya Wibawa S., M.Pd sebagai pemateri inti. Materi yang disampaikan secara umum ada dua, yaitu pagi; 1) teori tentang pelatihan dan profesi pelatih, 2) aplikasi teori dan praktik pembuatan program latihan pada sore hari.

\section{DAFTAR PUSTAKA}

Purnama, S. P., 2010. Kepelatihan Bulutangkis Modern. Yuma Pustaka. Surakarta.

Undang-Undang Republik Indonesia Nomor 3 Tahun 2005 Tentang Sistem Keolahragaan Nasional. Kementrian Pemuda Dan Olahraga. Jakarta.

Tim, 2017. Panduan Penelitian Dan Pengabdian Kepada Masyarakat Di Perguruan Tinggi Edisi XI. Direktorat Riset dan Pengabdian Kepada Masyarakat. Jakarta.

Sukri, et al., 2019. Panduan Penelitian Dan Pengabdian Kepada Masyarakat Internal Ikip Mataram. Institut Keguruan dan Ilmu Pendidikan Mataram. Lembaga Penelitian Pengabdian Kepada Masyarakat. Mataram. 